\title{
Changes in activity of certain enzymes in sea urchin embryos and larvae after exposure of adult organisms to heavy metals
}

\author{
V. B. Durkina, Z. S. Evtushenko \\ Institute of Marine Biology, Far Eastern Branch, USSR Academy of Sciences, Vladivostok 690 032, USSR
}

\begin{abstract}
The activity of acid and alkaline phosphatases, glucose-6-phosphatase, $\mathrm{Mg}^{2+}$-ATPase and glucose-6-phosphate dehydrogenase was investigated in embryos and larvae obtained from gametes of the sea urchin Strongylocentrotus nudus exposed for $30 \mathrm{~d}$ to increased zinc, copper and cadmium concentrations $\left(100,25\right.$ and $50 \mu \mathrm{g} \mathrm{l} \mathrm{l}^{-1}$, respectively). Exposure of parent sea urchins to zinc resulted in increased $\mathrm{Mg}^{2+}$-ATPase activity and clecreased glucose-6-phosphate degydrogenase activity in larvae at the stage of $2 \mathrm{~d}$ pluteus, followed by their death. Exposure of parents to copper resulted in accelerated development of larvae at the stage of early pluteus; exposure to cadmium led to no visible changes in larval development.
\end{abstract}

\section{INTRODUCTION}

Extended exposure of marine invertebrates to high concentrations of heavy metals causes an increase in the number of anomalous and non-viable embryos and larvae (Zaroogian \& Morrison 1981, Khristoforova et al. 1984). Deviations from normal development may result from changes in enzymic activities (Evola-Maltese 1957)

To elucidate the mechanism of heavy metals' effect on the offspring, a laboratory experiment was carried out with a long exposure of the sea urchin Strongylocentrotus nudus to increased concentrations of zinc, copper and cadmium, followed by determination of metal accumulation in eggs and measurement of activity of acid and alkaline phosphatases, glucose-6-phosphatase, $\mathrm{Mg}^{2+}$-ATPase and glucose-6-phosphate degydrogenase in the early stages of embryonic and larval development.

\section{MATERIAL AND METHODS}

The research was performed at the 'Vityaz' marine experimental base of the Far Eastern Branch of the USSR Academy of Sciences in June to August 1984. Four groups of adult sea urchins Strongylocentrotus nudus (each consisting of 35 individuals) were main- tained in 100 l aquaria of plastic glass with aerated seawater. The water was changed every $2 \mathrm{~d}$. One group was maintained in natural seawater (control). In the other 3 aquaria, after a regular water change, copper chloride, zinc chloride or cadmium chloride was added $\left(25 \mu \mathrm{g} \mathrm{Cu}{ }^{2+} 1^{-1}, 100 \mu \mathrm{g} \mathrm{Zn}^{2+} 1^{-1}\right.$ and $50 \mu \mathrm{g} \mathrm{Cd} \mathrm{Cd}^{2+}$ $1^{-1}$, respectively). The aquaria were maintained for $30 \mathrm{~d}$. Sea urchins were fed on sea algae, Laminaria and Ulva. Each portion of algae was utilized for $2 \mathrm{~d}$. After $16 \mathrm{~d}$ exposure to copper, the sea urchins no longer consumed all the food offered

At the end of the experiments, sex cells were obtained from 3 females and 3 males of each group. Within each group the eggs were pooled and used for subsequent work. After artificial fertilization of a small number of eggs the development of embryos of control and experimental groups was followed in 3 parallel experiments.

In the first experiment, embryos were cultivated in filtered seawater without additions of toxicants at $21^{\circ} \mathrm{C}$ in $0.2 \mathrm{l}$ beakers. At the zygote stages, 2 blastomeres, blastula and gastrula were selected, fixed with $0.2 \%$ formalin diluted with seawater and for each 100 embryos the number of normally developing specimens was calculated. Using the method of Naidenko (1983), the cultivation of remaining control and experimental larvae was continued at 21 to $23.5^{\circ} \mathrm{C}$ for $1 \mathrm{mo}$ until first juvenile sea urchins appeared. 
The largest proportion of eggs was placed into 21 glasses, fertilized and cultivated at constant stirring. At the stage of zygote, blastula, gastrula and $2 \mathrm{~d}$ pluteus, the activity of acid and alkaline phosphatases was determined (Sullivan \& Volcani 1974), as well as that of $\mathrm{Mg}^{2+}$-ATPase (Stewart 1974) and glucose-6-phosphatase (Barber \& Foy 1973); at the stages of gastrula and 2 d pluteus, the activity of glucose-6-phosphate dehydrogenase was determined (Kochetov 1980). Suspensions of embryos in $0.05 \mathrm{M}$ Tris-buffer $(\mathrm{pH} 7.5)$ were treated 3 times on an ultrasonic disintegrator UZDN-1 at $44 \mathrm{kHz}$ for $10 \mathrm{~s}$ to destroy cellular membranes and centrifuged at $16000 \times g$ for $20 \mathrm{~min}$. The supernatant was treated as an enzymic preparation and its protein content determined as described by Lowry et al. (1951).

The remaining part of the eggs from the control and experiments was dried at $85^{\circ} \mathrm{C}$ to constant weight. After acid mineralization, copper, zinc and cadmium content was measured using a Shimadzu AA-610 S flame atomic absorption spectrophotometer.

\section{RESULTS}

Metal contents in eggs from control and experimental groups of sea urchins are given in Table 1.

Table 1. Strongylocentrotus nudus. Zinc, copper and cadmium contents in eggs of sea urchins ( $\mu \mathrm{g} \mathrm{g}^{-1}$ dry mass) after $30 \mathrm{~d}$ exposure to increased concentrations of these metals in water. Means $\pm \mathrm{SD} ; \mathrm{n}=3$

\begin{tabular}{|c|c|c|c|}
\hline \multirow[t]{2}{*}{ Toxicant } & \multicolumn{3}{|c|}{ Content in eggs } \\
\hline & $\mathrm{Zn}$ & $\mathrm{Cu}$ & $\mathrm{Cd}$ \\
\hline Control & $3.6 \pm 0.2$ & $0.03 \pm 0.01$ & $0.03 \pm 0.01$ \\
\hline Zinc $\quad 100 \mu \mathrm{gl}^{-1}$ & $6.2 \pm 0.1 \cdots$ & $0.08 \pm 0.03$ & $0.01 \pm 0.01$ \\
\hline Copper $\quad 25 \mu^{-1} l^{-1}$ & $2.8 \pm 0.1^{\circ}$ & $0.10 \pm 0.03$ & $0.03 \pm 0.01$ \\
\hline Cadmium $50 \mathrm{ug} \mathrm{l}^{-1}$ & $3.6 \pm 0.1$ & $0.05 \pm 0.01$ & $0.03 \pm 0.01$ \\
\hline \multicolumn{4}{|c|}{$\begin{array}{l}\text { - Significantly different from control at } p<0.05 \\
\text { - Significantly different from control at } p<0.01\end{array}$} \\
\hline
\end{tabular}

In $\mathrm{Zn}$-exposed specimens an accumulation of the metal in eggs was observed. In experiments with $\mathrm{Cu}$ and $\mathrm{Cd}$, no accumulation in sex cells was observed.

The embryonic development of the offspring obtained from $\mathrm{Zn}$ - and Cd-exposed individuals was distinct from that in the control group (Table 2). Thus, 5 min after artifical fertilization the percentage of fertilized eggs was highest in the experiment with $\mathrm{Cd}$ and lowest in that with $\mathrm{Zn}$. However, 1 h $10 \mathrm{~min}$ after fertilization, the amount of unfertilized eggs was less than $10 \%$ in all groups except $\mathrm{Zn}$-exposed individuals. In the offspring of $\mathrm{Zn}$-exposed specimens, half of the eggs remained unfertilized. The percentage of normally developing blastulas obtained from Cd-exposed sea urchins was lower compared to the control. In gastrulas, the development of embryos was similar in all groups.

The development of offspring obtained from gametes of Zn-exposed sea urchins was unsuccessful: the larvae died at the pluteus stage with 2 pairs of arms (Fig. 1c). In the offspring obtained from gametes of Cu-exposed sea urchins, the third pair of arms was formed faster than in the control (Fig. 1a, b). Plutei obtained from gametes of Cd-exposed individuals (Fig. 1d) were similar to the control ones.

On the 31st to 33rd days of development in cultures of plutei obtained from gametes of control sea urchins and those exposed to $\mathrm{Cu}$ and $\mathrm{Cd}$, the first juveniles were found

Results for enzyme activities in embryos and larvae are given in Table 3 .

The activity of acid phosphatase in control embryos did not change during the process of development. In the offspring of $\mathrm{Zn}$-exposed specimens, a rise in the acid phosphatase activity occurred in zygote and blastula; in gastrulas, a decrease in this enzyme activity was observed, and in plutei, it was restored to the control value. In embryos of Cu-exposed sea urchins, the activity of the enzyme was increased at all stages. In the offspring of Cd-exposed individuals, an increase

Table 2. Strongylocentrotus nudus. Embryonic development of sea urchin offspring after $30 \mathrm{~d}$ exposure of adult specimens to increased zinc, copper and cadmium concentration in water. Values are percentages of individuals in the stage indicated which survived the previous stage; means $\pm S D_{i} n=3$

\begin{tabular}{|c|c|c|c|c|c|}
\hline \multirow[t]{2}{*}{ Age } & \multirow{2}{*}{$\begin{array}{l}\text { Stage of } \\
\text { development }\end{array}$} & \multicolumn{4}{|c|}{ Conditions of maintenance of adults } \\
\hline & & Control & $\mathrm{Zn}$ & $\mathrm{Cu}$ & $\mathrm{Cd}$ \\
\hline $5 \min$ & Zygote & $50.0 \pm 8.7$ & $38.3 \pm 6.1$ & $59.6 \pm 13.7$ & $83.0 \pm 4.6^{\circ}$ \\
\hline \multirow[t]{3}{*}{$1 \mathrm{~h} 10 \mathrm{~min}$} & 2 blastomeres & $75.0 \pm 2.1$ & $35.6 \pm: 9.0^{\circ}$ & $70.6 \pm 2.7$ & $84.0 \pm 5.1$ \\
\hline & Zygote & $22.3 \pm 2.0$ & $13.0 \pm 4.2$ & $19.3 \pm 1.7$ & $7.3 \pm 1.5^{\circ}$ \\
\hline & Unfertilized eggs & $1.3 \pm 1.3$ & $50.3 \pm 13.3^{\circ}$ & $4.6 \pm 1.5$ & $8.3 \pm 3.9$ \\
\hline $7 \mathrm{~h} 20 \mathrm{~min}$ & Blastula & $84.1 \pm 2.7$ & $80.0 \pm 1.1$ & $78.0 \pm 7.8$ & $68.3 \pm 3.1^{\circ}$ \\
\hline $20 \mathrm{~h} 30 \mathrm{~min}$ & Gastrula & $81.0 \pm 7.8$ & $79.1 \pm 6.5$ & $85.0 \pm 1.0$ & $74.3 \pm 8.7$ \\
\hline
\end{tabular}


of activity of the enzyme was observed at all stages with the exception of blastula.

The activity of alkaline phosphatase in control embryos and larvae increased during development. In the offspring of Zn-exposed sea urchins, a rise in activity was observed only in blastulas. In the offspring of $\mathrm{Cu}$ - and Cd-exposed individuals, the activity of alkaline phosphatase increased in the plutei as compared with the control.

The activity of glucose-6-phosphatase in control embryos and larvae was low. In experimental groups, the activity of this enzyme remained at the control level except for gastrula where it was not found.

The activity of $\mathrm{Mg}^{2+}$-ATPase in control larvae decreased during development. In the offspring of $\mathrm{Cu}$ and Cd-exposed sea urchins the activity of the enzyme did not differ reliably from the control. Exposure of sea urchins to an increased $\mathrm{Zn}$ concentration resulted in an inhibition of $\mathrm{Mg}^{2+}$-ATPase in gastrula and a sharp rise of activity in pluteus.

The activity of glucose-6-phosphate degydrogenase in control larvae did not practically differ in gastrula and pluteus stages. After Cu exposure, a decrease of enzymic activity was observed only in gastrulas, but it returned to control levels in plutei. After Cd exposure the activity of glucose-6-phosphate dehydrogenase in gastrulas was at
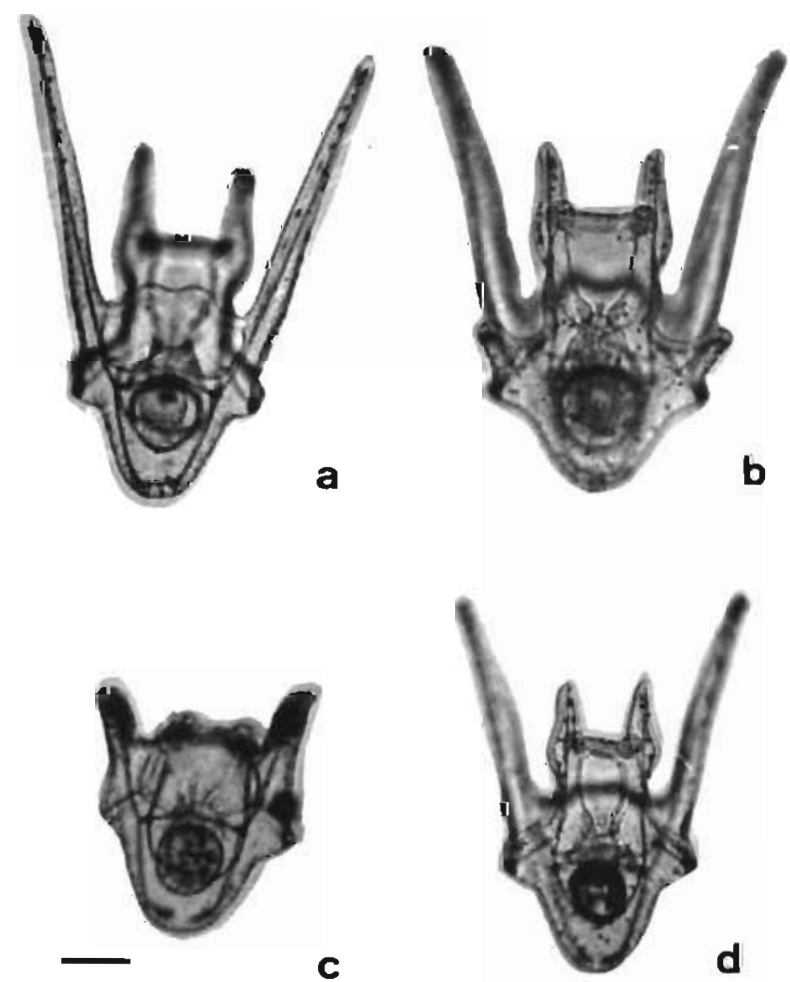

Fig. 1. Strongylocentrotus nudus. Plutei at age $9 \mathrm{~d}$ obtained from gametes of (a) controls, (b) copper-exposed, (c) zincexposed, (d) cadmium-exposed adults. $\mathrm{Bar}=100 \mu \mathrm{m}$ the control level, but it increased in the pluteus stage. In larvae obtained from gametes of $\mathrm{Zn}$-exposed sea urchins, the activity of the enzyme was reduced.

\section{DISCUSSION}

These experiments show that long-term exposure of sea urchins to zinc, as distinct from copper and cadmium, resulted in bioaccumulation of this metal in eggs. A decrease of the percentage of fertilized eggs seemed to be a manifestation of the toxicity effect of zinc on the offspring. The same picture was observed in the fish Brachydanio rerio after exposure to $5 \mathrm{mg} \mathrm{l}^{-1} \mathrm{Zn}$ for 9 d (Speranza et al. 1977).

In larvae obtained from gametes of Zn-exposed sea urchins, the activity of glucose-6-phosphate dehydrogenase and $\mathrm{Mg}^{2+}$-ATPase changed.

Glucose-6-phosphate dehydrogenase is a key enzyme for transformation of carbohydrates through the pentose phosphate cycle, the product of which is riboso-5 phosphate, an RNA structural component. In sea urchins this route of carbohydrate transformation predominates in the early developmental stages (Giudice 1973). The activity of glucose-6-phosphate dehydrogenase in embryos increases immediately after fertilization, continues increasing up to the start of gastrulation and then falls gradually (Backström 1959). In our experiments the enzyme activity in the control offspring in gastrula and pluteus stages was practically the same. In the offspring of $\mathrm{Zn}$-exposed specimens the enzyme activity was sharply decreased compared with the control. It was previously shown that treatment of sea urchin embryos with zinc sulphate solution resulted in a strong inhibition of synthesis of ribosomal RNA (Pirrone et al. 1970). Death of larvae obtained from gametes of $\mathrm{Zn}$-exposed parents seems to be connected with an inability to build their own protein-synthesizing apparatus, because in the period from mesenchymatous blastula to pluteus (age 70 to $80 \mathrm{~h}$ ), a gradual substitution of ribosomes produced in oogenesis by those synthesized by the embryo itself occurs (Nemer \& Infante 1967).

The activity of $\mathrm{Mg}^{2+}$-ATPase in the control offspring in gastrula was twice as high as that in plutei. Exposure of adults to $\mathrm{Zn}$ resulted in a reduction of the enzyme activity in gastrula and, in contrast, in its almost 3-fold increase in plutei. From literature data we known that $\mathrm{Zn}$ can both raise and reduce the activity of $\mathrm{Mg}^{2+}$. ATPase, which seems to be dependent on metal concentration and peculiarities of the studied tissues. Thus, in the rainbow trout Salmo gairdneri, the activity of $\mathrm{Mg}^{2+}$-ATPase in gills increased at $\mathrm{Zn}$ concentration $0.29 \mathrm{mg} \mathrm{l}^{-1}$ but remained constant at 0.99 and $1.98 \mathrm{mg}$ $1^{-1}$ (Watson \& Beamish 1980). In the crustacean 
Table 3. Stronglocentrotus nudus. Activity of enzymes in the offspring of sea urchin after 30 d exposure of adults to increased zinc, copper and cadmium concentrations. Means $\pm \mathrm{SD} ; \mathrm{n}=4$

\begin{tabular}{|c|c|c|c|c|c|c|}
\hline $\begin{array}{l}\text { Conditions of } \\
\text { maintenance }\end{array}$ & $\begin{array}{l}\text { Develop- } \\
\text { mental } \\
\text { stages }\end{array}$ & $\begin{array}{c}\text { Acid } \\
\text { phosphatase }\end{array}$ & $\begin{array}{l}\text { Alkaline } \\
\text { phosphatase } \\
\text { (ug P inorg. } \mathrm{h}^{-}\end{array}$ & $\begin{array}{r}\text { Glucose-6- } \\
\text { phophatase } \\
\text { mg }^{-1} \text { protein) }\end{array}$ & $\mathrm{Mg}^{2+}$-ATPase & $\begin{array}{l}\text { Glucose- } 6 \text {-phos- } \\
\text { phate dehydro- } \\
\text { genase (nmole } \\
\text { min }^{-1} \mathrm{mg}^{-1} \\
\text { protein) }\end{array}$ \\
\hline Control & $\begin{array}{l}\text { Zygote } \\
\text { Blastula } \\
\text { Gastrula } \\
\text { Pluteus }\end{array}$ & $\begin{array}{l}37.8 \pm 1.0 \\
33.1 \pm 2.6 \\
36.9 \pm 1.0 \\
41.3 \pm 3.0\end{array}$ & $\begin{array}{l}6.4 \pm 0.6 \\
6.2 \pm 0.5 \\
7.1 \pm 0.9 \\
8.5 \pm 0.1\end{array}$ & $\begin{array}{l}7.0 \pm 1.6 \\
7.6 \pm 0.4 \\
2.0 \pm 0.5 \\
1.6 \pm 0.4\end{array}$ & $\begin{array}{l}94.7 \pm 5.0 \\
96.6 \pm 5.8 \\
79.3 \pm 9.2 \\
39.3 \pm 5.0\end{array}$ & $\begin{array}{c}- \\
- \\
39.0 \pm 6.6 \\
38.7 \pm 0.6\end{array}$ \\
\hline $\begin{array}{l}\text { Zinc } \\
100 \mu \mathrm{g} \mathrm{l}^{-1}\end{array}$ & $\begin{array}{l}\text { Zygote } \\
\text { Blastula } \\
\text { Gastrula } \\
\text { Pluteus }\end{array}$ & $\begin{array}{l}46.2 \pm 1.6^{\circ} \\
46.8 \pm 2.0^{\circ} \\
23.3 \pm 2.1^{\circ} \\
40.9 \pm 1.6\end{array}$ & $\begin{array}{l}7.2 \pm 0.5 \\
8.7 \pm 0.5 \\
6.6 \pm 0.1 \\
9.9 \pm 0.7\end{array}$ & $\begin{array}{c}10.5 \pm 0.3 \\
9.3 \pm 0.7 \\
\text { nd } \\
1.2 \pm 0.0\end{array}$ & $\begin{array}{c}108.0 \pm 7.2 \\
100.6 \pm 11.5 \\
31.3 \pm 8.1 \\
86.6 \pm 11.5^{\circ}\end{array}$ & $\begin{array}{c}- \\
- \\
8.7 \pm 2.4 \cdots \\
12.2 \pm 2.2 \cdots\end{array}$ \\
\hline $\begin{array}{l}\text { Copper } \\
25 \mu \mathrm{g} \mathrm{l}^{-1}\end{array}$ & $\begin{array}{l}\text { Zygote } \\
\text { Blastula } \\
\text { Gastrula } \\
\text { Pluteus }\end{array}$ & $\begin{array}{l}53.4 \pm 1.6^{\cdots} \\
55.4 \pm 3.0^{\cdots} \\
50.5 \pm 0.2 \cdots \\
64.3 \pm 0.5 \cdots\end{array}$ & $\begin{array}{r}6.5 \pm 0.6 \\
6.5 \pm 0.8 \\
8.2 \pm 0.9 \\
11.8 \pm 0.8\end{array}$ & $\begin{array}{c}11.4 \pm 0.6 \\
11.6 \pm 0.7 \cdots \\
\text { nd } \\
1.9 \pm 0.2\end{array}$ & $\begin{array}{c}103.3 \pm 5.7 \\
101.3 \pm 2.3 \\
70.0 \pm 10.0 \\
55.0 \pm 3.2\end{array}$ & $\begin{array}{c}- \\
- \\
32.3 \pm 1.5^{\circ} \\
47.5 \pm 5.0\end{array}$ \\
\hline $\begin{array}{l}\text { Cadmium } \\
50 \mu \mathrm{g}^{-1}\end{array}$ & $\begin{array}{l}\text { Zygote } \\
\text { Blastula } \\
\text { Gastrula } \\
\text { Pluteus }\end{array}$ & $\begin{array}{l}51.1 \pm 2.2^{\cdots} \\
44.0 \pm 3.2 \\
42.7 \pm 0.6^{\circ} \\
52.8 \pm 2.0^{\circ}\end{array}$ & $\begin{array}{c}7.0 \pm 0.3 \\
7.3 \pm 0.6 \\
7.4 \pm 0.3 \\
11.5 \pm 0.7^{\circ}\end{array}$ & $\begin{array}{c}11.8 \pm 0.3^{\circ} \\
10.4 \pm 0.3 \\
\text { nd } \\
1.9 \pm 0.2\end{array}$ & $\begin{array}{l}90.0 \pm 17.3 \\
98.0 \pm 3.5 \\
63.3 \pm 5.7 \\
49.0 \pm 6.4\end{array}$ & $\begin{array}{c}- \\
- \\
35.5 \pm 5.2 \\
67.0 \pm 9.2^{\circ}\end{array}$ \\
\hline $\begin{array}{l}\text { - Significantl } \\
\cdots \text { Significantl } \\
\text { nd: not detecte } \\
\text {-: not measure }\end{array}$ & $\begin{array}{l}\text { erent fron } \\
\text { erent from }\end{array}$ & $\begin{array}{l}\text { ol at } p<0.05 \\
\text { ol at } p<0.01\end{array}$ & & & & \\
\hline
\end{tabular}

Homarus americanus, a $\mathrm{Zn}$ concentration of $25 \mathrm{mg} \mathrm{l}^{-1}$ inhibited the activity of gill ATPases; when the lobsters were placed into clean water the activity of enzymes was not restored (Haya et al. 1983).

The activity of glucose-6-phosphatase in the control offspring was at practically the same level in zygote and blastula and decreased sharply in gastrula and in pluteus. After exposure of adults to increased concentrations of heavy metals, the activity of this enzyme was not observed in the offspring in gastrula stage, whereas in pluteus it appeared again. it is well-known that most embryonic enzymes are already present in the egg. In the process of development, they are replaced by molecules synthesized by the embryo itself. For example, in sea urchins, after late gastrula stage, genetic control of aldolase and esterase synthesis was observed (Neifakh \& Timofeeva 1978). It is possible that, in our case, restoration of glucose-6-phosphatase activity in the pluteus is connected with the effect of embryonic genome.

The exposure of sea urchins to increased metal concentrations resulted in a increase of acid phosphatase activity in embryos and larvae. Measurements of this lysosomal enzyme activity in the sea urchin Strongylocentrotus purpuratus inhabiting polluted environments (Jenkins et al. 1982), in the fish Heteropneustes fossilis (Sastry \& Subhadra 1985) and in the bivalve Protothaca staminea (Roesijadi 1980) in experimental conditions show its tissue specificity and dependence on metal concentrations. In our experiments the increased activity of acid phosphatase seems to result from the stress effect of toxicants on the parents.

In conclusion, a long exposure of sea urchins to increased $\mathrm{Zn}$ concentrations resulted in inhibition of glucose-6-phosphate dehydrogenase and activation of $\mathrm{Mg}^{2+}$-ATPase in larvae and their death. In the offspring of Cu-exposed individuals, an acceleration in development was observed in the stage of early pluteus. In the experiment with $\mathrm{Cd}$, the change in activity of certain enzymes in embryos and larvae did not influence the development of the sea urchins.

\section{LITERATURE CITED}

Backström, S. (1959). Activity of glucose-6-phosphate dehydrogenase in sea urchin embryos of different developmental trends. Expl. Cell Res. 18: 347-356

Barber, M. L., Foy, J. E. (1973). An enzymic comparison of sea urchin egg ghosts prepared before and after fertilization. J. exp. Zool. 184: 157-166

Evola-Maltese, C. (1957). Effects of beryllium on the development and alkaline phosphatase activity of Paracentrotus lividus embrio. Acta Embryol. Morph. exp. 1. 143

Giudice, G. (1973). Developmental biology of the sea urchin embryo. Academic Press, New York

Haya, K. Waiwood, B. A., Johnston, D. W (1983). Adenilate 
energy charge and ATPase activity of lobster (Homarus americanus) during sublethal exposure to zinc. Aquat. Toxic. 3: 115-126

Jenkins, K. D., Brown, D. A., Oshida, P. S., Perkins, E. M. (1982). Cytosolic metal distribution as an indicator of toxicity in sea urchins from the southern California Bight. Mar. Pollut. Bull. 13: 413-421

Khristoforova, N. K., Gnezdilova, S. M., Vasova, G. A. (1984). Effect of cadmium on gametogenesis and offspring of the sea urchin Strongylocentrotus intermedius. Mar Ecol. Prog. Ser. 17: 9-14

Kochetov, G. A. (1980). A practical guide on enzymology. High School, Moscow (in Russian)

Lowry, O. H., Rosebrough, N. G., Farr, A. Z., Randall, R. G. (1951). Protein measurement with the Folin phenol reagent. J. biol. Chem. 193: 265-275

Naidenko, T. Kh. (1983). Laboratory cultivation of sea urchin Strongylocentrotus intermedius. Biol. Morya, Vladivostok 9: 46-50 (in Russian)

Neifakh, A. A., Timofeeva, M. Ya. (1978). Problems of regulation in molecular developmental biology. Nauka, Moscow

Nemer, M., Infante, A. A. (1967). Ribosomal ribonucleic acid of sea urchin egg and its fate during embryogenesis. J. molec. Biol. 27: 73-86

Pirrone, A. M., Sconzo, G., Mitolo, V., Giudice, G. (1970). Effect of chemical animalization and vegetalization on the

This article was presented by V. Kasyanov, Vladivostok, USSR synthesis of ribosomal RNA in sea urchin embryos. Wilhelm Roux Arch. EntwMech. Org. 164: 222

Roesijadi, G. (1980). Influence of copper on the clam Protothaca staminea: effects on gills and occurrence of copper-binding proteins. Biol. Bull. mar. biol. Lab., Woods Hole 158: 233-247

Sastry, K. V., Subhadra, K. (1985). In vivo effects of cadmium on some enzyme activities in tissue of the freshwater catfish, Heteropneustes fossilis. Envir. Res. 36: 32-45

Speranza, A. W. Seeley, R. J., Seeley, V A., Permutter, A. (1977). The effect of sublethal concentrations of zinc on reproduction in zebrafish, Brachydanio rerio HamiltonBuchanan. Envir. Pollut. 12: 217-222

Stewart, D. J. (1974) Sensitive automated methods for phosphate and $\left(\mathrm{Na}^{+}, \mathrm{K}^{+}\right)$-ATPase. Analyt. Biochem. 62: 349-364

Sullivan, C. W., Volcani, B. E. (1974). Isolation and characterization of plasma and smooth membranes of the marine diatom Nitzschia alba. Archs. Biochem. Biophys. 163: $29-45$

Watson, T. A., Beamish, F. W. H. (1980). Effects of zinc on branchial ATPase activity in vivo in rainbow trout, Salmo gairdnen. Comp. Biochem. Physiol. 66: 77-82

Zaroogian, G. E., Morrison, G. (1981). Effect of cadmium body burdens in adult Crassostrea virginica on fecundity and viability of larvae. Bull. envir. Contam. Toxic. 27: 344-348

Manuscript first received: August 1, 1990

Revised version accepted: February 8, 1991 